pp.309-324. Oxford.

Leonhard, M.L. and M.B. Fenton (1983). Habitat use by spotted bats (Euderma maculatum): roosting and foraging behaviour. Canadian Journal of Zoology 61: 1487-1491.

Limpens, H.J.G., W. Helmer, A. Winden and K. Mostert (1989). Bats and linear landscape. Lutra 32: 1-20.

Mackey, R.I. and M.R. Barclay (1989). Influence of physical clutter on activity of bat over water. Canadian Journal of Zoology 67: 11671170

McGeachie, W.J. (1989). Effect of moonlight illuminance, temperature and wind speed on light trap catches of moth. Bulletin of Entomological Research 79: 185-192.

Mills, A.M. (1986). The influence of moonlight on the behaviour of goatsuckers. Auk 103: 370-378.

Neuweiler, G. (1984). Foraging, echolocation and audition in bats, Naturwissenschaften 71: 446-455.

Rydell, J., A. Entwistle and P.A. Racey (1996). Timing of foraging flights of three species of bats in relation to insect activity and predation risk. Oikos 76: 243-252.

Shmida, A. (1990). Handbook of Wild Flowers of Israel Desert Flora. Ketter Publishing House Ltd.

Speakman, J.R. (1995). Chiropteran Nocturnality, pp. 187-201. Oxford.

Stebbings, R.E. (1968). Measurement, composition and behaviour of large colonial bats. Journal of Zoology 156: 15-33.

Swift, M.S. (1980). Activity patterns of Pipistrelle bats (Pipstrellus pipstrellus) in Northeast Scotland. Journal of Zoology 190: 285-295.

Taylor, L.R. (1986). Time series analysis of number of Lepidoptera caught at light traps in East Africa and the effects of moonlight on trapped efficiency. Bulletin of Entomological Research 76: 593-606.

Verable, L.S.V. (1943). Observation at Pipistrelle bat roost. Journal of Animal Ecology 12: 19-26.

von Frenckell, B., and R.M.R. Barclay (1987). Bat activity over calm and turbulent water. Canadian Journal of Zoology 65: 219-222.

\section{CATTLE EGRET (BUBULCUS IBIS) ATTEMPTING TO FEED ON BROWN ROCK CHAT (CERCOMELA FUSCA) CHICK}

\author{
R.M. Kasambe
}

Wildlife and Environment Conservation Society, M.R. Colony MIDC Bypass, Amravati 444606, India.

On 17 May 2001 at $0545 \mathrm{hr}$ when I was watching birds, I found four Brown Rock Chats (Cercomela fusca Blyth ) making loud noises and hovering over a Cattle Egret (Bubulcus ibis). The latter was holding a small bird alive in its beak and striking it on the ground. When I approached the bird it dropped the prey and flew away. The prey was a chick of Brown Rock Chat and soon the chick died from serious injuries near its neck, both shoulders and thighs. I left the dead chick and retreated to observe the behaviour of the four Brown Rock Chats until 0645hr. The four birds hovered restlessly and noisily over the dead chick. These birds had not attacked the predator when the Cattle Egret was holding the chick in its beak.

One Brown Rock Chat sat on a soil mound, the other two birds sat at some distance at a construction site and the fourth one first flew over the dead chick, tried to keep flying over it for few seconds uttering short harsh calls. Then it sat very close to the dead chick (on one foot) with opened wings and fluttered vigorously. It bent forward with lifted tail and gave harsh calls to the chick. Again it flew over the chick for few seconds and repeated the same behaviour described above for half an hour. After every few displays the bird sat on the soil mound or at the construction site while another bird took over. This way each bird took turns to guard the dead chick.

At $0645 \mathrm{hr}$, even though ants had started eating the dead chick, the four birds were still trying to guard the dead chick. 